\title{
Long-Term Infusions of Ghrelin and Obestatin in Early Lactation Dairy Cows
}

\author{
J. R. Roche, ${ }^{\star 1}$ A. J. Sheahan, ${ }^{\star}$ L. M. Chagas, ${ }^{\star}$ D. Blache,† D. P. Berry,‡ and J. K. Kay* \\ *DairyNZ, Hamilton, New Zealand \\ †University of Western Australia, Perth, Australia \\ ¥Teagasc Moorepark, Fermoy, Co. Cork, Ireland
}

\begin{abstract}
Ghrelin is an endogenous ligand of the growth hormone secretagogue receptor and a potential orexigenic agent in monogastrics and ruminants. Obestatin has been reported to have the opposite (anorexigenic) effect. Fifty one multiparous cows were randomly allocated to 1 of 3 groups $(\mathrm{n}=17)$ : a control group and 2 groups with cows continuously infused with $0.74 \mu \mathrm{mol} / \mathrm{d}$ of ghrelin (GHR group) or obestatin (OBE group) subcutaneously. Infusions began $21 \mathrm{~d}$ in milk, and treatments continued for 8 wk. Generalized linear models were used to determine the treatment effect on average daily and cumulative milk production and composition, and plasma ghrelin, growth hormone, insulin-like growth factor (IGF)-1, leptin, nonesterified fatty acids, and glucose. Mixed models, with cow included as a repeated effect, were used to determine if treatment effects differed by week postcalving for milk production, body weight, and body condition score (BCS; scale 1 to 10). Parity, breed, week of the year at calving, treatment, week postcalving, and the $2 \mathrm{wk}$ preexperimental average of each measure (covariate) were included as fixed effects. Treatment did not affect dry matter intake. Cows infused with GHR lost more BCS ( -0.71 units) over the 8-wk study period than the control $(-0.23$ BCS units) cows, and on average were thinner than cows in either of the other 2 treatments (0.2 BCS units). Consistent with the extra BCS loss in GHR cows, plasma IGF-1, glucose, and leptin concentrations were reduced and plasma nonesterified fatty acid concentrations were greater in GHR cows. Despite a numerical tendency for GHR cows to produce more milk $(1,779 \mathrm{~kg})$ than control $(1,681 \mathrm{~kg})$ or OBE $(1,714 \mathrm{~kg})$ cows during the 8 -wk period, milk production differences were not statistically different. However, the timing of the numerical separation of the lactation curves coincided with the significant changes in BCS, IGF-1, and leptin. Results indicate a positive effect of ghrelin infusion on lipolysis. Further research
\end{abstract}

Received March 18, 2008.

Accepted August 6, 2008

${ }^{1}$ Corresponding author: john.roche@DairyNZ.co.nz is required to determine if the numerical increase in milk production, which coincides with the increased negative energy balance, is real.

Key words: neuroendocrine, appetite, hunger, grazing

\section{INTRODUCTION}

Forbes and Provenza (2000) suggested that the understanding of factors controlling food intake and diet selection should be a challenge that occupies a prominent place in the fields of nutrition and physiology. Dry matter intake is arguably the most important factor in animal production, dictating the amount of nutrients available for production and thereby determining gross feed conversion efficiency (i.e., proportion of nutrients consumed that are directed to production-related processes).

Although overly simplistic to reduce a behavior as complex as feeding to a series of molecular interactions (Stanley et al., 2005), extensive research into the effect of hypothalamic lesions in the 1950s (Kennedy, 1953) and the discovery of numerous peptides that are produced in response to feeding or food deprivation have provided a greater understanding of physiological factors that alter feeding behavior (Stanley et al., 2005). Over the last decade, important advances have been made in the characterization of hypothalamic neuronal networks and neuropeptide transmitters, along with the discovery of circulating peptides that signal the brain regarding the body's nutritional status (Stanley et al., 2005).

One such peptide is ghrelin, a 27-amino acid compound produced predominantly in the oxyntic gland cells of the abomasum (Hayashida et al., 2001). It is the endogenous ligand for the growth hormone secretagogue receptor (Kojima et al., 1999) and the only known peripherally active, orexigenic (appetite stimulating), peptide hormone. In monogastrics and ruminants, the pattern of ghrelin release suggests that it governs the sensation of hunger (Murphy and Bloom, 2006). Plasma ghrelin concentrations increase during food restriction (Sugino et al., 2002) and decline postprandially (Roche et al., 2006, 2007); they are negatively correlated with 
body tissue reserves (Shiiya et al., 2002; Roche et al., 2007), consistent with the lipostatic theory (Kennedy, 1953) that animals alter DMI to maintain a set level of adiposity. In addition, plasma ghrelin concentrations decline within minutes of an intravenous glucose challenge (Roche et al., 2008b), highlighting that its secretion is not related to gastric distension, but is more likely a result of circulating signals of energy state.

In agreement with these associative data, exogenously administered ghrelin has increased DMI in humans (Neary et al., 2004), rodents (Nakahara et al. 2003), sheep (Harrison et al., 2008), and beef cattle (WertzLutz et al., 2006), and increased milk production in rats (Nakahara et al., 2003). In dairy cattle, infused ghrelin has been reported to increase growth hormone (Itoh et al., 2005) and blood glucose (Itoh et al., 2006), and physiological effects appear more evident in lactating compared with nonlactating cows (Itoh et al., 2005). Results also indicate an effect of ghrelin infusion on pancreatic hormone concentrations (Itoh et al., 2006). There are no data on the effect of ghrelin on DMI in dairy cows. Furthermore, no study has continuously infused ghrelin for an extended period.

Obestatin is a recently discovered 23-amino acid ghrelin-associated peptide, derived from posttranslational processing of the prepro-ghrelin gene with a flanking conserved glycine residue at the end C-terminus (Zhang et al., 2005). It has been reported to have the opposite effect to ghrelin, reducing food intake and gastric transit, and decreasing $\mathrm{BW}$ gain upon chronic peripheral injection (Zhang et al., 2005; Lagaud et al., 2007). There are no data on the effect of this hormone in dairy cows.

Obestatin has, however, also been the subject of much recent controversy. The initial work of Zhang et al. (2005) reported obestatin to be the endogenous ligand for the G protein-coupled receptor 39. Subsequent research has found no such relationship and the reported effects on DMI have been inconsistent (Nogueiras et al., 2007; Zhang et al., 2007; Zizzari et al., 2007).

As the genetic selection for milk production has resulted in increased circulating concentrations of ghrelin (Roche et al., 2006), and this may result in increased circulating obestatin, because of their common origin, it is important to determine the effect of these hormones on important production and health-related traits. The primary objective of the proposed study was to determine if there was an effect of long-term exogenous administration of ghrelin and obestatin on DM and energy intake, milk production, BCS and BW change, and metabolic and hormonal indicators of energy status in early lactation dairy cows grazing fresh pasture and supplemented with grain-based concentrates.

\section{MATERIALS AND METHODS}

This experiment was conducted at Lye Farm, DairyNZ, Hamilton, New Zealand $\left(37^{\circ} 46^{\prime} \mathrm{S} 175^{\circ} 18^{\prime} \mathrm{E}\right)$ from July to September 2006, and all procedures were approved by the Ruakura Animal Ethics Committee, Hamilton, New Zealand.

\section{Experimental Design and Treatments}

Cows. Fifty-one multiparous cows were blocked in wk 4 of lactation according to DIM, parity, and milk yield during wk 2 and 3 of lactation; they were then randomly allocated within block (randomized block design) into 3 experimental groups, ensuring calving date (July $17 \pm 5.2 \mathrm{~d}$ ), parity $(4.3 \pm 1.81)$, preexperimental BW (498 $\pm 51.2 \mathrm{~kg})$, BCS (4.6 $\pm 0.38 ; 10$-point scale; Roche et al., 2004), and milk production $(27.7 \pm 3.88$ $\mathrm{kg}$ of milk/d; $1.3 \pm 0.17 \mathrm{~kg}$ of fat $/ \mathrm{d} ; 1.0 \pm 0.14 \mathrm{~kg}$ of protein $/ \mathrm{d} ; 4.7 \pm 0.60 \%$ fat; $3.7 \pm 0.20 \%$ protein) were balanced across treatment.

Hormones for Infusion. Obestatin results from the proteolysis of proghrelin between amino acid 76 and 98 of the preproghrelin sequence (Garg, 2007). Synthetic bovine obestatin (FNAPFNIGIKLAGAQSLQHGQTL-NH ${ }_{2}$, molecular weight $=2,548 \mathrm{~g} / \mathrm{mol}$ ) was synthesized by Peptides International (Louisville, KY). [Dap (2, 3-diaminopropanoic acid)-octanoyl ${ }^{3}$-human ghrelin ([ $\left.\mathbf{D a p}^{3}\right]$-ghrelin; H-GS-Dap(n-octanoyl)-FL$\mathrm{NH}_{2}$; molecular weight $=633.79 \mathrm{~g} / \mathrm{mol}$ ), a pentapeptide made up of the first 5 residues of ghrelin but with 2,3-diaminopropionic acid incorporated in place of $\mathrm{Ser}^{3}$, and the $\beta$-amino group of this new residue acylated with $n$-octanoic acid was also obtained from Peptides International Inc. (cat. no. PGH-3681-PI). Bednarek et al. (2000) noted that short peptides encompassing the first 5 residues of ghrelin functionally activated the growth hormone secretagogue receptor as efficiently as the full-length peptide. Iqbal et al. (2006) subsequently evaluated $\left[\mathrm{Dap}^{3}\right]$-ghrelin in sheep and found it to be an even more potent growth hormone secretagogue than ovine ghrelin, verifying its effectiveness in ruminant animals.

The advantage of using $\left[\mathrm{Dap}^{3}\right]$-ghrelin was its small molecular mass (approximately 20\% that of full-length ghrelin), allowing the infusion experiment to be undertaken with minimal pump insertion. The disadvantage is that the peptide cannot be quantified by the commercially available RIA kits for ghrelin determination, and therefore treatment success could not be verified via plasma ghrelin concentrations.

Experimental Design. Experimental groups included an untreated control (control), whereas cows in 
the other 2 groups received an 8-wk continuous infusion (subcutaneously) with $0.742 \mu \mathrm{mol} / \mathrm{d}(0.007 \mu \mathrm{mol} / \mathrm{kg}$ of $\mathrm{BW}^{0.75}$ per d) of $\left[\mathrm{Dap}^{3}\right]$-ghrelin (GHR group) or obestatin (OBE group).

The ghrelin dose used was equivalent to that administered by Nakahara et al. (2003; $0.007 \mu \mathrm{mol} / \mathrm{kg}$ of $\mathrm{BW}^{0.75}$ per d) to rats when they observed an increase in milk production following a twice-daily subcutaneous administration of ghrelin (assuming a Wistar rat BW of $320 \mathrm{~g}$ ). The daily dose administered was 66 times greater than that administered as a single dose by Wertz-Lutz et al. (2006), when they observed an increase in DMI and time spent feeding in the $60 \mathrm{~min}$ postinfusion in cattle. The half life of ghrelin is between 15 and $30 \mathrm{~min}$; thus, the 20-min dose rate in the current experiment is similar to the single injection administered by WertzLutz et al. (2006; $0.0001 \mu \mathrm{mol} / \mathrm{kg}$ of $\left.\mathrm{BW}^{0.75}\right)$.

The continuous subcutaneous infusion was administered via miniature, implantable osmotic pumps (Alzet Model 2ML4, cat. no. 0000327, Braintree Scientific Inc., Braintree, MA). The pumps were $5.1 \mathrm{~cm}$ in length and $1.4 \mathrm{~cm}$ in diameter, and released $2.5 \mu \mathrm{L}$ of solution $/ \mathrm{h}$ at a constant rate for $28 \mathrm{~d}$; the daily dose delivered from the pumps was calculated using the delivery rate information supplied with each lot of pumps. The $\left[\mathrm{Dap}^{3}\right]$-ghrelin was reconstituted from a lyophilized powder into a $50 \%$ solution of dimethylsulfoxide (D8418, Sigma Chemical, St. Louis, MO) at a rate of 1 $\mathrm{mg} / 125 \mu \mathrm{L}$ of dimethylsulfoxide. The bovine obestatin was reconstituted into a $3 \%$ solution of acetic acid at a rate of $1 \mathrm{mg} / 50 \mu \mathrm{L}$ of acetic acid.

The pumps were weighed, along with the flow modulator, and filled using the blunt-tipped 25-gauge filling tube provided, ensuring no air bubbles entered the pump. The fill volume was more than $90 \%$ of the reservoir volume indicated in the lot specifications (as specified in instructions). The pumps were then primed in a $0.9 \%$ saline solution (Baxter, Auckland, New Zealand) overnight at $37^{\circ} \mathrm{C}$.

One and 2 pumps were inserted into cows on the GHR and OBE treatments, respectively, on $21 \pm 1.9$ and 49 \pm 1.6 DIM (mean $\pm \mathrm{SD}$ ). The pumps were implanted in the loose skin on the right side of the neck just dorsal to the jugular vein. After $28 \mathrm{~d}$ the original pumps were removed and a new set inserted in the loose skin on the left side of the neck. Implantation sites were shaved and disinfected, and a local anesthetic administered before pumps were inserted. Incisions were closed using wound clips.

\section{Pasture Management and Supplementary Feeds}

Cows were rotationally grazed as one herd for the duration of the experiment and only returned to the same area when a minimum of 2 leaves had appeared on the majority $(>75 \%)$ of perennial ryegrass tillers. Cows had access to a fresh allocation of pasture twice daily. Pasture allowance ( $>40 \mathrm{~kg}$ of $\mathrm{DM} /$ cow per $\mathrm{d}$ ) was sufficient to ensure unrestricted DMI (up to approximately $20 \mathrm{~kg}$ of $\mathrm{DM} / \mathrm{d}$ ) of fresh pasture. Average $( \pm \mathrm{SD})$ pre- and postgrazing pasture mass was 2,744 $\pm 180.4 \mathrm{~kg}$ of $\mathrm{DM} / \mathrm{ha}$ and $2,017 \pm 142.2 \mathrm{~kg}$ of DM/ ha, respectively. The high postgrazing residuals were to ensure that cow intake was not restricted. Water was available ad libitum in each grazing area.

The grazed pasture was of high quality throughout the experiment, and consisted of $89 \%( \pm 3.1$; mean $\pm \mathrm{SD})$ perennial ryegrass leaf, $2 \%( \pm 1.7)$ perennial ryegrass stem, $6 \%( \pm 4.1)$ white clover (Trifolium repens L.), $1 \%( \pm 2.3)$ weeds and other grasses (Dactylus glomerata, Holcus lanatus, and some Poa species), and $2 \%$ $( \pm 1.0)$ dead material on a DM basis. Chemical analyses confirmed the high pasture quality $(\mathrm{CP}=24.3 \pm 2.40 \%$ of $\mathrm{DM} ; \mathrm{NDF}=38.4 \pm 3.02 \%$ of $\mathrm{DM} ; \mathrm{ADF}=20.4 \pm$ $1.05 \%$ of DM; lipid $=4.1 \pm 0.18 \%$ of DM; $\mathrm{NSC}=16.8$ $\pm 2.98 \%$ of DM; OM digestibility $>84.0 \%$ of $\mathrm{DM}$; $\mathrm{ME}$ $>12.5 \mathrm{MJ} / \mathrm{kg}$ of $\mathrm{DM})$.

A flat rate of $4.5 \mathrm{~kg}$ of DM of concentrates $(32 \%$ crushed barley, $60 \%$ crushed maize), $2 \%$ broll (milling by-product), $6 \%$ molasses; $\mathrm{CP}=14.1 \pm 0.16 \%$ of $\mathrm{DM}$; $\mathrm{NDF}=16.8 \pm 0.47 \%$ of $\mathrm{DM} ; \mathrm{ADF}=7.7 \pm 0.39 \%$ of $\mathrm{DM}$; lipid $=3.5 \pm 0.19 \%$ of $\mathrm{DM} ; \mathrm{NSC}=56.7 \pm 0.62 \%$ of DM) was split equally in 2 feeds daily during milking. During wk 2 and 3 of the experiment, the cows were also offered $2.2( \pm 0.95) \mathrm{kg}$ of DM pasture silage/ cow daily $(\mathrm{CP}=17.1 \pm 1.15 \%$ of $\mathrm{DM}$; OM digestibility $=68.2 \pm 2.62 \%$ of $\mathrm{DM}$; $\mathrm{NDF}=59.5 \pm 0.91 \%$ of $\mathrm{DM}$; $\mathrm{ADF}=38.9 \pm 0.98 \%$ of DM; lipid $=3.4 \pm 0.25 \%$ of $\mathrm{DM} ; \mathrm{NSC}<1 \%$ of $\mathrm{DM} ; \mathrm{ME}=10.9 \pm 0.42 \mathrm{MJ} / \mathrm{kg}$ of $\mathrm{DM})$.

\section{Pasture Measurements}

Compressed pasture height was measured using a rising plate meter installed with an electronic counter (Farmworks, Palmerston North, New Zealand), which had been calibrated to the pastures used in this experiment. Briefly, on $3 \mathrm{~d}$ each wk, pasture samples (n $=40$ ) from each treatment group were cut to ground level within rectangular quadrats $\left(0.125 \mathrm{~m}^{2}\right)$ placed randomly within pasture allocations to be grazed the following day and those grazed during the previous 24 h. Compressed pasture heights were measured inside each $0.125 \mathrm{~m}^{2}$ quadrat before cutting. The cut pasture samples were washed to remove soil contamination and dried at $100^{\circ} \mathrm{C}$ to constant weight (for approximately $72 \mathrm{~h}$ ). Resultant DM yield/0.125 $\mathrm{m}^{2}$ was converted to 
DM yield/ha. These data were used to develop a regression equation relating pasture height to mass.

$$
\begin{gathered}
\text { Pasture mass }(\mathrm{kg} \text { of } \mathrm{DM} / \mathrm{ha})=27.8 \times \text { height }(\mathrm{mm}) \\
+818.5 ; \\
P<0.001 ; \mathrm{r}^{2}=0.76 ; \mathrm{n}=315 .
\end{gathered}
$$

Pasture height measurements $(\mathrm{n}=200)$ were recorded in pastures to be grazed, the pasture mass estimated from the regression equation, and this figure used to allocate the desired grazing area. One hundred pasture height measurements were recorded in the allocated daily grazing area before and after each grazing.

Representative samples of pasture were collected daily by plucking pasture to grazing height from paddocks due to be grazed. Similarly, representative samples of the grain and silage offered to cows were collected daily. Samples were bulked on a twice-weekly basis, and duplicate samples were dried at $100^{\circ} \mathrm{C}$, for $\mathrm{DM}$ analysis, or $60^{\circ} \mathrm{C}$ for analysis of nutrient composition. These samples were dried at $60^{\circ} \mathrm{C}$ for $48 \mathrm{~h}$, ground to pass through a 1.0-mm sieve (Christy Lab Mill, Suffolk, UK), and analyzed for CP, NDF, ADF, NSC, lipid, and OM digestibility by near infrared spectroscopy. Metabolizable energy was derived directly from predicted OM digestibility.

\section{Animal Measurements}

DMI. Individual animal intake estimates were obtained at pasture 5 to 6 wk postpump insertion using the n-alkane technique outlined by Kennedy et al. (2003). Briefly, each cow was dosed twice daily (at milking) for a 10-d period with a pellet containing 356 $\mathrm{mg}$ of $\mathrm{n}$-dotriacontane (C32; i.e., $712 \mathrm{mg}$ of C32/cow per day). Fecal grab samples were collected twice daily from each cow (after milking) during the last $5 \mathrm{~d}$ of the 10-d period. The fecal samples from each cow for the 5 - $\mathrm{d}$ period were then bulked and stored at $-17^{\circ} \mathrm{C}$ awaiting alkane analysis. During the same 5-d period, pasture samples were plucked to grazing height, following close observation of the grazing animal, to represent pasture grazed. The n-alkane contents (C25-C36) of the pasture and feces were determined using gas chromatography.

The ratio of herbage C33 (tritriacontane) to dosed C32 was used to estimate pasture intake. Estimates of daily herbage intake were calculated as follows:

Daily pasture DMI $(\mathrm{kg} / \mathrm{cow})=\frac{\mathrm{F}_{\mathrm{i}} / \mathrm{F}_{\mathrm{j}} \cdot\left(\mathrm{D}_{\mathrm{j}}+\mathrm{I}_{\mathrm{S}} \cdot \mathrm{S}_{\mathrm{j}}\right)-\mathrm{I}_{\mathrm{S}} \cdot \mathrm{S}_{\mathrm{i}}}{\mathrm{P}_{\mathrm{i}}-\left(\mathrm{P}_{\mathrm{j}} \cdot \mathrm{F}_{\mathrm{i}} / \mathrm{F}_{\mathrm{j}}\right)}$, where $\mathrm{F}_{\mathrm{i}}, \mathrm{S}_{\mathrm{i}}$, and $\mathrm{P}_{\mathrm{i}}$ are the concentrations $(\mathrm{mg} / \mathrm{kg}$ of $\mathrm{DM}$ ) of the natural odd-chain n-alkane (C33) in feces, supplement, and pasture, respectively, $F_{j}, S_{j}$, and $P_{j}$ are the concentrations $(\mathrm{mg} / \mathrm{kg}$ of $\mathrm{DM})$ of the dosed evenchain n-alkane (C32) in feces, supplements, and pasture, respectively, and $D_{j}$ and $I_{S}$ are the dose rate $(\mathrm{mg} / \mathrm{d})$ of the even-chain n-alkane (C32) and supplement intake, respectively.

Milk and $\boldsymbol{B} \boldsymbol{W}$. Individual milk yields were recorded daily (Westfalia Surge, Oelde, Germany). Fat, CP, and lactose concentrations of milk were determined by Milkoscan (Foss Electric, Hillerød, Denmark) on individual afternoon and morning aliquot samples collected on $2 \mathrm{~d}$ each week. Milk component data were verified by reference techniques for a subset of milk samples (milk fat, Röse-Gottlieb; CP, macro-Kjeldahl techniques).

Body weight and BCS were determined every week following the morning milking. Body condition score was assessed on a 10-point scale, where 1 is emaciated and 10 is obese (Roche et al., 2004). These scores can be converted to the 5-point scale using the regression equation generated by Roche et al. (2004; 5 -point scale $=1.5+0.32 \times 10$-point scale).

Milk Fatty Acids. During wk 7 of the experimental period, milk fat was extracted from the fresh milk samples using the Röse-Gottlieb fat extraction procedure and stored at $-20^{\circ} \mathrm{C}$ until analysis for fatty acid composition.

Fatty acid methyl esters were quantified by gas chromatography after methylation using sodium methoxide as described by MacGibbon (1988). Gas chromatographic analyses of fatty acid methyl esters were performed on a GC-17A equipped with a flame ionization detector, auto-sampler, and auto-injector (Shimadzu Corporation, Kyoto, Japan). A 120-m BPX-70 column $(120 \mathrm{~m} \times 0.25 \mathrm{~mm}$ i.d. and $0.25-\mu \mathrm{m}$ film thickness; SGE, Ringwood, Victoria, Australia) was used, and 0.2 $\mu \mathrm{L}$ of solvent solution was injected using on-column injection technique combined with programmed temperature volatilization. The initial temperature was set at $80^{\circ} \mathrm{C}$ for $0.1 \mathrm{~min}$ and then ramped to $230^{\circ} \mathrm{C}$ at a rate of $250^{\circ} \mathrm{C} / \mathrm{min}$. The initial oven temperature was $80^{\circ} \mathrm{C}$, then ramped to $190^{\circ} \mathrm{C}$ at a rate of $2^{\circ} \mathrm{C} / \mathrm{min}$ and held for $25 \mathrm{~min}$. Injector and detector temperature was set at $250^{\circ} \mathrm{C}$.

Standards for conjugated linoleic acid and other fatty acids were obtained from Matreya Inc. (Pleasant Gap, PA) and conjugated linoleic acid isomer mixes from Sigma Chemical and NuChek Prep (Elysian, MN). In addition, a butter reference standard (CRM 164; Commission of the European Communities, Community Bureau of Reference, Brussels, Belgium) was used as a qualitative reference for individual fatty acids, and 
GLC 87 and 74X (NuChek Prep) were used as quantitative methyl ester references.

Blood. Blood was sampled on $1 \mathrm{~d}$ every $2 \mathrm{wk}$; two $10-\mathrm{mL}$ evacuated blood tubes (140 IU of sodium heparin and $0.117 \mathrm{~mL}$ of $15 \% \mathrm{~K}_{3} \mathrm{EDTA}$ ) were collected from each cow by coccygeal venipuncture before the a.m. milking (approximately $0730 \mathrm{~h}$ ). Following centrifugation $\left(1,120 \times g, 12 \mathrm{~min}, 4^{\circ} \mathrm{C}\right)$ and extraction, plasma from the sodium heparin tubes were frozen, and plasma from the EDTA-blood tubes was acidified using $1.0 \mathrm{~N}$ $\mathrm{HCl}$ and treated with phenylmethylsulfonyl fluoride $\left(\mathrm{C}_{7} \mathrm{H}_{7} \mathrm{FO}_{2} \mathrm{~S}\right.$ ), as per kit instructions (Ghrelin Active Kit, Linco Research Inc., St. Charles, MO), before storage and analysis for plasma ghrelin concentration.

Analyses for NEFA (colorimetric method) and glucose (hexakinase method) were performed on a Hitachi 717 analyzer (Roche, Basel, Switzerland) at $30^{\circ} \mathrm{C}$ by Alpha Scientific Ltd., Hamilton, New Zealand. The inter- and intraassay CV was $<2 \%$ for NEFA and glucose. Growth hormone (Downing et al., 1995), IGF-1 (Gluckman et al., 1983), insulin (Hales and Randle, 1963), and leptin (Blache et al., 2000) were measured in duplicate by double-antibody RIA with an inter- and intraassay CV $<6 \%$.

Validation of Active-Ghrelin Kit. Plasma ghrelin concentrations were determined using the ActiveGhrelin RIA kit (cat. no. GHRA-88HK, Linco Research Inc.), which uses a double antibody/PEG technique. The kit is specific for the biologically active form of ghrelin, using ${ }^{125}$ I-labeled ghrelin and a ghrelin antiserum. Because the kit is designed for human samples, a validation process was undertaken for use with bovine blood. The manufacturer's protocol was followed and standard validations, including parallelism and recovery, conducted.

Parallelism ensures the assay maintains linearity under dilution, and recovery of exogenous active ghrelin verifies accurate measurement throughout the working range of the assay. Serial dilutions (1:1, 1:2, 1:4, $1: 8$, and 1:16) of 4 bovine plasma samples in triplicate yielded curves that were parallel to the standard curve. Evident parallelism was good, with slopes of -0.77 and -0.79 (average of 4 sample slopes) for the standard curve and serially diluted bovine samples, respectively. Recovery was tested by analyzing 4 bovine samples, each with 4 different known exogenous ghrelin concentrations (range $=50$ to $400 \mathrm{pg} / \mathrm{mL}$; concentrations chosen to correspond to ghrelin concentrations from actual samples).

Recovery of exogenous ghrelin was acceptable, with a range of 81 to $108 \%$ and an overall average of $91.6 \%$. Inter- and intraassay variations were performed on 10 bovine plasma samples, over 3 separate assays, containing varying concentrations of ghrelin (range $=28.7$ to
$429.9 \mathrm{pg} / \mathrm{mL}$ ). The assay produced an overall intraassay CV of $7.3 \% \pm 11.3$ and an interassay CV of $6.4 \%$ \pm 8.9 .

\section{Data Analyses}

Because one cow died midway through the lactation (OBE treatment) and problems with the pump were encountered for another cow (GHR treatment), both cows were removed from the analyses and a total of 49 cows were available for inclusion: 17 control animals, 16 animals infused with ghrelin, and 16 animals infused with obestatin. The number of animals in parity 2 to 8 was $11,10,7,8,4,8$, and 1 , respectively; animals that were parity 5 or greater were grouped. Production data were available for all animals up to wk 10 postcalving (wk 7 postpump insertion); data after this point were excluded from the analysis.

Milk Production, DMI, BW, and BCS. With the exception of DMI, where the data were not available, covariates were calculated as the average of each of the production variables in wk 2 and 3 postcalving. Average daily production for each week from wk 4 to 10 postcalving (i.e., wk 1 to 7 postpump insertion), inclusive, were retained as the dependent variable. $\mathrm{Cu}-$ mulative milk production from wk 4 to 10 postcalving, inclusive, was calculated, as were changes in BW and BCS from wk 3 to 11 postcalving.

Two methods of analysis were used. Generalized linear models using PROC GLM (SAS, 2007) were used to determine the effect of treatment on cumulative milk production, DMI, and BCS and BW change; parity was included in the model as a fixed effect and the covariate corresponding to the dependent variable included as a continuous variable. For the analysis of daily milk production and weekly BW and BCS, a mixed model (PROC MIXED, SAS, 2007) was used, including week postpump insertion as a repeated effect within cow, whereas parity and the covariate corresponding to the dependent variable, and interactions between treatment and week postpump insertion, were included as fixed effects. Based on the Akaike information criterion, an unstructured covariance matrix was assumed among records within cow. The covariance structures tested were based on biological plausibility and included unstructured, compound symmetry (with or without heterogeneous variances) and first-order autoregressive covariance structures (with or without heterogenous variances) for each time point.

Blood Parameters. All blood parameters were analyzed using mixed models in PROC MIXED (SAS, 2007); week postpump insertion was included as a repeated effect within cow, with a compound symmetry covariance structure with heterogeneous variances as- 
sumed among weeks within cow. Each blood parameter was analyzed separately and a covariate for the respective parameter, sampled immediately before pump insertion, was included in the analysis. Fixed effects tested for inclusion in the multiple regression model, other than treatment and week postpump insertion, were parity, breed, and week of calving. The significance of an interaction between treatment $\times$ week postpump insertion was also tested in the model.

\section{RESULTS}

The volume of residual peptide solution in implanted pumps was as predicted from defined release, indicating successful implementation of treatment infusions. Table 1 summarizes the effect of treatment on DMI, cumulative yield of milk and milk components, and mean milk composition over the experimental period. There was no significant effect of treatment on pasture or total DMI. Figure 1 portrays weekly changes in daily milk yield. Although there was a numerical increase in milk yield in animals infused with ghrelin, a result of an apparent separation of the lactation profiles at wk 3 postpump insertion, the treatments were not significantly different at any week postpump insertion. Similarly, neither ghrelin nor obestatin infusion resulted in a significant change in milk composition, nor was there a significant interaction between treatment and time postpump insertion.
A more detailed examination of the milk fat profile indicated an effect of treatment on short chain fatty acids (Table 2), with lesser proportions of de novo synthesized short chain fatty acids (C4 to $\mathrm{C} 15: 1)$ in cows infused with ghrelin or obestatin and a lesser yield of all of the short-chain fatty acids in obestatin-infused cows relative to the control group. Yields of long-chain fatty acids also tended to be less in obestatin-infused cows; in particular, yields of stearic acid (C18:0) were less $(P$ $<0.05)$ in obestatin cows than the control.

Ghrelin-infused cows lost more BCS than control cows (Table 1), but the effect of treatment on BCS differed $(P<0.05)$ with time (Figure 2$)$. There was no effect of ghrelin or obestatin infusion in the weeks immediately following pump insertion. However, from 3 wk postpump insertion, cows infused with ghrelin lost more BCS $(P<0.01)$ when compared with the control cows, and at a greater rate than cows in either of the other 2 treatments $(P<0.05 ; 0.02 \pm 0.023,-0.08$ \pm 0.026 , and $-0.04 \pm 0.025$ BCS units/d for control, GHR, and OBE treatment groups, respectively; mean \pm SE). Body weight was not affected $(P=0.55)$ by treatment, with a mean BW (SE) of 506 (3.2), 501 (3.6), and 504 (3.4) $\mathrm{kg}$ for control, GHR, and OBE cows, respectively. Similarly, there was no effect of treatment on BW change postpump insertion (Table 1).

Table 3 summarizes the effect of treatment on the least squares means of measured plasma metabolite and hormone concentrations averaged across the ex-

Table 1. Effect (SE in parentheses) of a continuous infusion ${ }^{1}$ of $0.74 \mu \mathrm{mol} / \mathrm{d}\left(0.007 \mu \mathrm{mol} / \mathrm{kg}\right.$ of $\mathrm{BW}^{0.75}$ per d) [Dap (2,3-diaminopropanoic acid)-octanoyl ${ }^{3}$-ghrelin (human, rat, 1 to 5 ) or obestatin (bovine) in dairy cows in early lactation on $\mathrm{DMI}^{2}$ ( $\mathrm{kg}$ of DM/cow), cumulative milk production $(\mathrm{kg} / \mathrm{cow})$, and average milk composition (\%), BCS, ${ }^{3}$ and $\mathrm{BW}(\mathrm{kg})$ change

\begin{tabular}{|c|c|c|c|c|}
\hline \multirow[b]{2}{*}{ Trait } & \multicolumn{3}{|c|}{ Treatment } & \multirow[b]{2}{*}{$P$-value } \\
\hline & Control & Ghrelin & Obestatin & \\
\hline \multicolumn{5}{|l|}{ DMI } \\
\hline Pasture & $16.6(0.65)$ & $15.8(0.62)$ & $16.4(0.60)$ & 0.65 \\
\hline Concentrates & $4.5(0.25)$ & $4.2(0.24)$ & $4.3(0.23)$ & 0.65 \\
\hline Total & $21.1(0.64)$ & $20.1(0.61)$ & $20.8(0.59)$ & 0.44 \\
\hline \multicolumn{5}{|c|}{ Cumulative yield } \\
\hline Milk & $1,499(40.1)$ & $1,569(38.4)$ & $1,519(36.9)$ & 0.41 \\
\hline Fat & $63(1.5)$ & $61(1.4)$ & $60(1.3)$ & 0.29 \\
\hline Protein & $54(1.0)$ & $56(1.0)$ & $55(1.0)$ & 0.42 \\
\hline Lactose & $72(1.8)$ & $76(1.8)$ & $73(1.8)$ & 0.26 \\
\hline \multicolumn{5}{|c|}{ Milk composition } \\
\hline Fat & $4.2(0.12)$ & $4.0(0.12)$ & $4.0(0.12)$ & 0.47 \\
\hline Protein & $3.6(0.04)$ & $3.6(0.04)$ & $3.6(0.04)$ & 0.38 \\
\hline Lactose & $4.9(0.02)$ & $4.9(0.02)$ & $4.8(0.02)$ & 0.47 \\
\hline BW change & $6.9(7.25)$ & $7.2(7.10)$ & $14.9(6.67)$ & 0.66 \\
\hline BCS change & $-0.23^{\mathrm{a}}(0.125)$ & $-0.71^{\mathrm{b}}(0.121)$ & $-0.45^{\mathrm{ab}}(0.115)$ & $<0.05$ \\
\hline
\end{tabular}




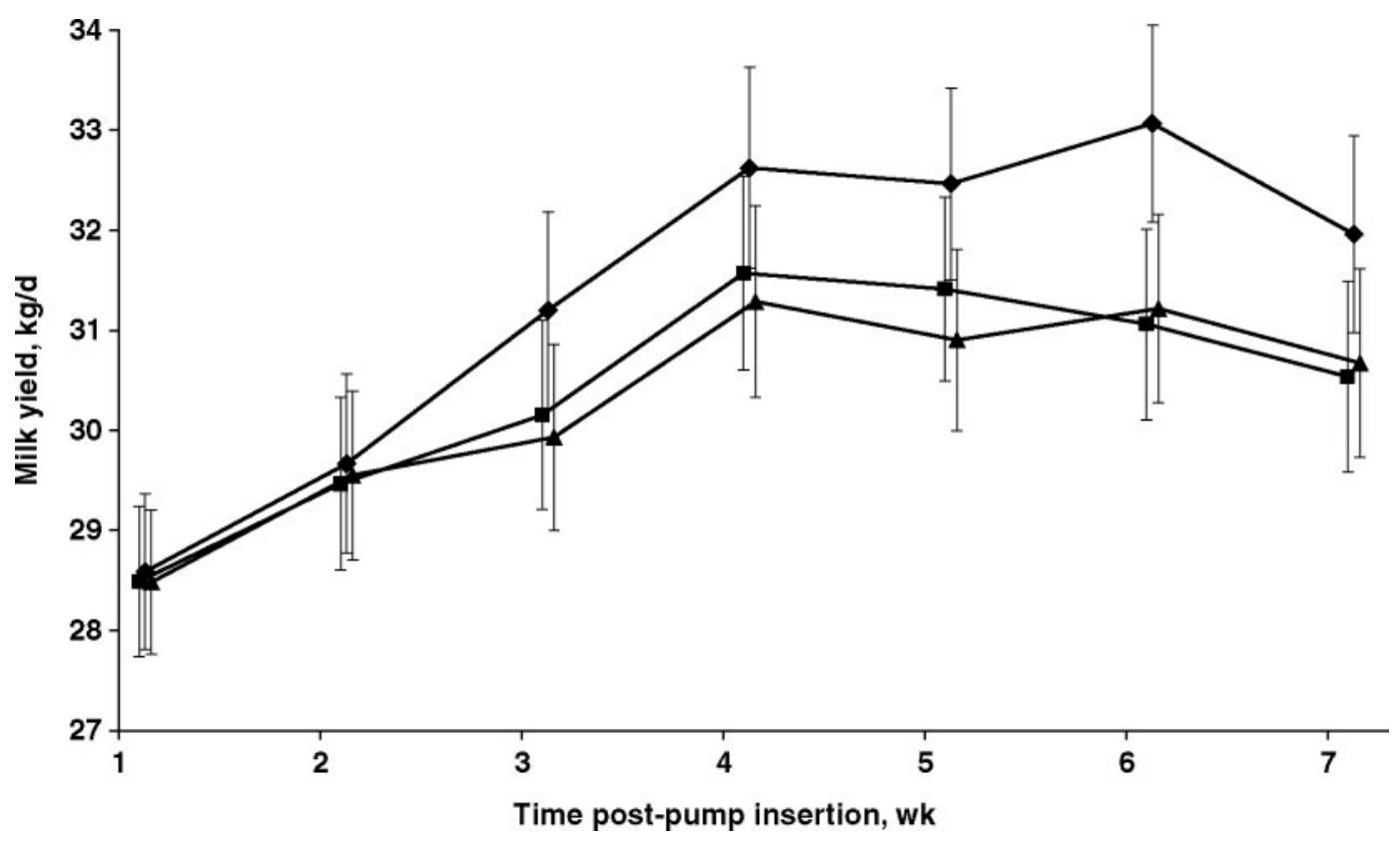

Figure 1. Least squares means $( \pm \mathrm{SD})$ of milk yield $(\mathrm{kg} / \mathrm{d})$ from early lactation dairy cows grazing pasture and supplemented with $4.4 \mathrm{~kg}$ of $\mathrm{DM} / \mathrm{d}$ of concentrate (control group; $\mathbf{0})$, and continuously infused with $0.74 \mu \mathrm{mol} / \mathrm{d}\left(0.007 \mu \mathrm{mol} / \mathrm{kg}\right.$ of BW ${ }^{0.75}$ per d) [Dap (2, 3-diaminopropanoic acid)-octanoyl ${ }^{3}$ ]-ghrelin (human; ) or obestatin (bovine; $\mathbf{\Delta}$ ) for $7 \mathrm{wk}$.

perimental period. Ghrelin infusion increased plasma NEFA concentration above that of the other 2 groups and decreased plasma IGF-1 and glucose concentration relative to the control. Plasma leptin concentrations were less $(P<0.05)$ in GHR cows compared with those infused with obestatin and tended $(P<0.10)$ to be less than control cows. Collectively, these data, along with the greater BCS loss, indicate a greater negative energy balance in cows infused with ghrelin than cows in the other 2 groups. There was an interaction $(P<0.05)$ between treatment and week postpump insertion on plasma IGF-1 and leptin concentrations. Cows infused with ghrelin, although having similar IGF-1 concentrations to the other treatments at pump insertion, had lesser IGF-1 concentrations after wk 4 postpump insertion. Similarly, plasma leptin concentration was not different between treatments at pump insertion, whereas GHR cows had lesser plasma leptin concentrations after wk 3 postpump insertion. Treatment had no significant effect on plasma ghrelin, growth hormone, or insulin.

\section{DISCUSSION}

Continuous infusion of early lactation dairy cows with ghrelin or obestatin did not significantly affect daily pasture or total DMI, or milk production, although there was a numerical separation of the milk production profiles $3 \mathrm{wk}$ postpump infusion. Increased BCS loss and greater plasma NEFA concentrations in ghrelin-infused cows, and a consistent negative effect of ghrelin on plasma glucose, IGF-1, and leptin concentrations indicate a greater negative energy balance in these cows. The timing of the ghrelin-induced effect on BCS loss and lesser plasma IGF-1 and leptin concentrations coincides with the numerical increase in milk production in GHR cows; this is consistent with a physiological effect of ghrelin on adipose tissue metabolism and possibly milk production.

\section{DMI}

Ghrelin. Since its discovery, ghrelin has been heralded as the most potent peripherally active orexigenic agent known (Tschop et al., 2004). In support of its importance in such a fundamental survival process as intake, ghrelin biology is very well preserved across species, and there is even evidence that ghrelin-like substances are universally present in all living organisms, including plants and microbes, where they are believed to be involved in the search for nutrients (Aydin et al., 2006). However, although several studies have reported the orexigenic action of exogenous ghrelin in humans (Neary et al., 2004), rodents (Nakahara et al., 2003), sheep (Harrison et al., 2008), and beef cattle (WertzLutz et al., 2006), to date no one has reported the effect of exogenous ghrelin infusion on DMI or milk production in dairy cattle, despite a published growth hormone secreting effect in dairy cattle (Itoh et al., 
Table 2. Effect (SE in parentheses) of a continuous infusion ${ }^{1}$ of $0.74 \mu \mathrm{mol} / \mathrm{d}\left(0.007 \mu \mathrm{mol} / \mathrm{kg}\right.$ of $\mathrm{BW}^{0.75}$ per d) [Dap (2,3-diaminopropanoic acid)-octanoyl $l^{3}$-ghrelin (human, rat, 1 to 5 ) or obestatin (bovine) in dairy cows in early lactation on milk fatty acid $^{2}$ composition and molar yield

\begin{tabular}{|c|c|c|c|c|}
\hline \multirow[b]{2}{*}{ Item } & \multicolumn{3}{|c|}{ Treatment } & \multirow[b]{2}{*}{$P$-value } \\
\hline & Control & Ghrelin & Obestatin & \\
\hline \multicolumn{5}{|l|}{ Fatty acid, \% } \\
\hline $4: 0$ to $15: 1$ & $27.8^{\mathrm{b}}(0.37)$ & $26.1^{\mathrm{a}}(0.39)$ & $26.1^{\mathrm{a}}(0.37)$ & $<0.01$ \\
\hline $16: 0$ to $16: 1$ & $26.6(0.83)$ & $26.6(0.87)$ & $26.2(0.83)$ & 0.90 \\
\hline $17: 0$ to $20: 0$ & $35.7(0.78)$ & $37.1(0.82)$ & $36.1(0.78)$ & 0.45 \\
\hline 18:0 & $10.4(0.55)$ & $9.7(0.58)$ & $9.3(0.55)$ & 0.39 \\
\hline trans-11 $18: 1^{3}$ & $4.1(0.38)$ & $4.1(0.40)$ & $4.4(0.38)$ & 0.85 \\
\hline trans-12 18:1 & $1.8(0.49)$ & $2.1(0.51)$ & $2.6(0.49)$ & 0.49 \\
\hline cis-9 18:1 & $14.6(0.59)$ & $15.3(0.62)$ & $14.5(0.59)$ & 0.58 \\
\hline $\mathrm{CLA}^{4}$ & $1.3(0.14)$ & $1.5(0.15)$ & $1.4(0.14)$ & 0.73 \\
\hline $18: 2^{5}$ & $1.1(0.05)$ & $1.1(0.05)$ & $1.1(0.05)$ & 0.77 \\
\hline $18: 3^{6}$ & $0.91(0.059)$ & $0.89(0.062)$ & $0.93(0.059)$ & 0.91 \\
\hline \multicolumn{5}{|c|}{ Fatty acid, mmol/d } \\
\hline $4: 0$ to $15: 1$ & $2,694^{\mathrm{b}}(128.0)$ & $2,416^{\mathrm{ab}}(134.9)$ & $2,175^{\mathrm{a}}(128.0)$ & $<0.05$ \\
\hline $16: 0$ to $16: 1$ & $1,675(97.9)$ & $1,548(103.2)$ & $1,406(97.9)$ & 0.17 \\
\hline $17: 0$ to $20: 0$ & $2,012(87.8)$ & $1,984(92.6)$ & $1,741(87.8)$ & 0.08 \\
\hline 18:0 & $583^{\mathrm{b}}(40.3)$ & $525^{\mathrm{ab}}(42.5)$ & $443^{\mathrm{a}}(40.3)$ & 0.07 \\
\hline trans-11 $18: 1^{3}$ & $233(20.8)$ & $220(21.9)$ & $211(20.8)$ & 0.76 \\
\hline trans-12 18:1 & $97(18.9)$ & $107(20.0)$ & $123(18.9)$ & 0.63 \\
\hline cis-9 18:1 & 824 (49.4) & $830(52.1)$ & 706 (49.4) & 0.16 \\
\hline CLA & $75(7.6)$ & $78(8.1)$ & $70(7.6)$ & 0.76 \\
\hline $18: 2^{5}$ & $63(2.8)$ & $60(3.0)$ & $53(2.8)$ & 0.06 \\
\hline $18: 3^{6}$ & $51(2.6)$ & $47(2.8)$ & $45(2.6)$ & 0.21 \\
\hline Total & $6,919^{\mathrm{b}}(302.0)$ & $6,494^{\mathrm{ab}}(318.3)$ & $5,874^{\mathrm{a}}(302.0)$ & 0.07 \\
\hline
\end{tabular}

${ }^{\mathrm{a}, \mathrm{b}}$ Different superscript letters denote significant differences within treatment means $(P<0.05)$.

${ }^{1}$ Administered subcutaneously via miniature, implantable osmotic pumps.

${ }^{2}$ Measurements are during wk 7 postpump insertion.

${ }^{3}$ Vaccenic acid.

${ }^{4}$ Cis-9, trans-11 conjugated linoleic acid.

${ }^{5}$ Linoleic acid.

${ }^{6}$ Linolenic acid.

2005) and a positive effect of ghrelin infusion on milk production in rats (Nakahara et al., 2003); neither has anyone continuously infused octanoylated-ghrelin over an extended period.

There was no evident effect of ghrelin on DMI in the study reported here, and this is consistent with the results of Iqbal et al. (2006), who reported no effect of intracerebroventricular or jugular-infused ghrelin on DMI in sheep. In comparison, Wertz-Lutz et al. (2006) reported an increase in both time spent eating and DMI in steers infused with sufficient ghrelin to raise plasma concentrations to preprandial concentrations (similar to the infusion rate in the current experiment). One of the reasons for the inconsistency among published studies may be the duration over which DMI was measured. Iqbal et al. (2006) reported no effect of ghrelin administration on daily DMI. However, the effect of ghrelin on DMI is rapid. Wertz-Lutz et al. (2006) recorded an increase in time spent feeding and DMI during the hour immediately postinfusion, but noted no effect of ghrelin infusion on either variable across the day. Similarly, Harrison et al. (2008) observed an immediate effect of ghrelin following intracerebroventricular infusion of ghrelin in sheep, but the effect was not significant over a longer time course. It appears from the work of Wertz-Lutz et al. (2006) and Harrison et al. (2008) that measurement of DMI over a time period much greater than $1 \mathrm{~h}$ postinfusion will not provide the orexigenic effects of ghrelin because of the dilution of the effect with time.

However, in the study reported here, ghrelin was infused continuously, thereby removing the time dilution factor as a likely reason for the lack of a treatment effect on DMI. There are 2 other likely possibilities. Longterm infusion of any hormone may lead to a reduction in its endogenous production. There have been no studies where ghrelin has been infused for the length of time examined in the present experiment, and so there are no data to support or refute this hypothesis. The [DAP $]$ ghrelin cannot be quantified by commercially available ghrelin RIA kits because of its short chain length. Because ghrelin concentrations were not different across treatments in the current study, the results indicate that endogenous production was not affected by ghrelin 
or obestatin infusion. A more detailed portrayal of the temporal pattern of plasma hormone and metabolite concentrations was presented by Roche et al. (2008a); the data indicated that $\left[\mathrm{Dap}^{3}\right]$-ghrelin had no effect on plasma ghrelin concentration throughout the day, but increased plasma growth hormone concentration during periods of feeding inactivity, confirming effectiveness of the infusion treatment. Furthermore, the evident effect of ghrelin on lipolysis in the current study indicates a physiological effect of exogenous infusion.

Another possible reason for the lack of a DMI effect is the stage of lactation at which the study was undertaken (wk 3 to 11 of lactation) and DMI measured (wk 8 to 9 of lactation). Voluntary feed intake increases gradually for about 12 wk postpartum in dairy cows (Ingvartsen and Andersen, 2000), and it is possible
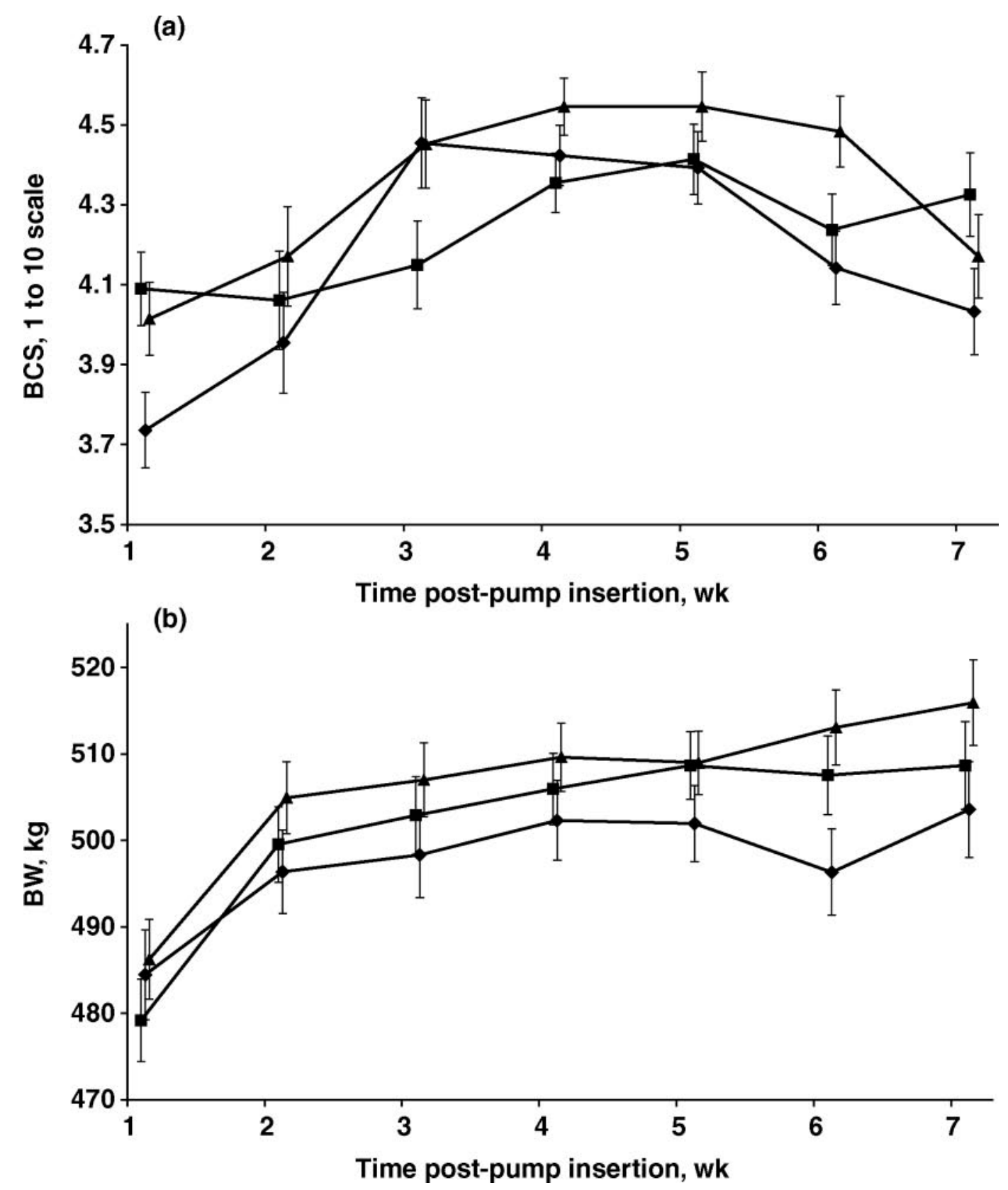

Figure 2. Least squares means $( \pm \mathrm{SD})$ of BCS $(\mathrm{a})$ and $\mathrm{BW}(\mathrm{b} ; \mathrm{kg})$ from early lactation dairy cows grazing pasture and supplemented with $4.4 \mathrm{~kg}$ of DM/d of concentrate (control; $\mathbf{0})$, and continuously infused with $0.742 \mu \mathrm{mol} / \mathrm{d}\left(0.007 \mu \mathrm{mol} / \mathrm{kg}^{\circ}\right.$ of BW ${ }^{0.75}$ per d) [Dap $(2,3$-diaminopropanoic acid)-octanoyl ${ }^{3}$ ]-ghrelin (human; $)$ or obestatin (bovine; $\mathbf{\Delta}$ ) for 7 wk. 
Table 3. Effect (SE in parentheses) of a continuous infusion ${ }^{1}$ of $0.74 \mu \mathrm{mol} / \mathrm{d}\left(0.007 \mu \mathrm{mol} / \mathrm{kg}\right.$ of BW $\mathrm{BW}^{0.75}$ per d) [Dap (2, 3-diaminopropanoic acid)octanoyl $^{3}$-ghrelin (human, rat, 1 to 5 ) or obestatin (bovine) in dairy cows in early lactation on the mean concentration ${ }^{2}$ of plasma metabolites and hormones

\begin{tabular}{|c|c|c|c|c|}
\hline Item & \multicolumn{3}{|c|}{ Treatment } & $P$-value \\
\hline Ghrelin, ng/L & $\begin{array}{l}302.1 \\
(5.71 \pm 0.067)\end{array}$ & $\begin{array}{l}324.7 \\
(5.78 \pm 0.065)\end{array}$ & $\begin{array}{l}357.4 \\
(5.88 \pm 0.062)\end{array}$ & 0.19 \\
\hline Leptin, $\mu \mathrm{g} / \mathrm{L}$ & $\begin{array}{c}0.61^{\mathrm{ab}} \\
(-0.50 \pm 0.032)\end{array}$ & $\begin{array}{c}0.57^{\mathrm{a}} \\
(-0.56 \pm 0.033)\end{array}$ & $\begin{array}{c}0.63^{\mathrm{b}} \\
(-0.46 \pm 0.032)\end{array}$ & 0.08 \\
\hline NEFA, mmol/L & $\begin{array}{c}0.22^{\mathrm{a}} \\
(-1.52 \pm 0.091)\end{array}$ & $\begin{array}{c}0.30^{\mathrm{b}} \\
(-1.21 \pm 0.089)\end{array}$ & $\begin{array}{c}0.22^{\mathrm{a}} \\
(-1.51 \pm 0.084)\end{array}$ & $<0.05$ \\
\hline Growth hormone, $\mu \mathrm{g} / \mathrm{L}$ & $\begin{array}{c}1.7 \\
(0.53 \pm 0.052)\end{array}$ & $\begin{array}{c}1.7 \\
(0.51 \pm 0.053)\end{array}$ & $\begin{array}{c}1.7 \\
(0.55 \pm 0.049)\end{array}$ & 0.82 \\
\hline Insulin, $\mu \mathrm{g} / \mathrm{L}$ & $\begin{array}{c}3.1 \\
1.13 \pm 0.087\end{array}$ & $\begin{array}{c}2.8 \\
1.04 \pm 0.091\end{array}$ & $\begin{array}{c}2.9 \\
1.08 \pm 0.091\end{array}$ & 0.79 \\
\hline Glucose, $\mathrm{mmol} / \mathrm{L}$ & $\begin{array}{l}1.10 \mathrm{I} \text { b.0or } \\
3.8^{\mathrm{b}} \\
(0.05)\end{array}$ & $\begin{array}{l}1.04 \pm 0.091 \\
3.6^{\mathrm{a}} \\
(0.05)\end{array}$ & $\begin{array}{l}1.001 .091 \\
3.7^{\mathrm{ab}} \\
(0.05)\end{array}$ & $<0.05$ \\
\hline
\end{tabular}

${ }^{\mathrm{a}, \mathrm{b}}$ Different superscript letters denote significant differences within treatment means $(P<0.05)$.

${ }^{1}$ Administered subcutaneously via miniature, implantable osmotic pumps.

${ }^{2}$ Data, other than glucose, were not normally distributed and required a $\log _{\mathrm{e}}$ transformation; back-transformed means are presented with LSM and SE on the transformed scale underneath in parentheses.

that an infusion of ghrelin before the cow achieves peak intake is unable to increase DMI. This is similar to the lack of effect of bST on milk yield and DMI before 60 DIM (Richards et al., 1985). In contrast, substantial increases in milk yield occur when bST is administered after peak milk yield is attained. Bauman (1992) related the biological basis for this early lactation lack of effect to the nutrition-endocrine status of the animal, the cow failing to respond to exogenous bST while in a state of negative energy balance. It is conceivable that the same could be true for ghrelin. Plasma ghrelin concentrations are greatest in early lactation, declining as lactation progresses (Itoh et al., 2005), consistent with the profile of DMI through lactation. Their data also point to an interaction between the ghrelin effect on growth hormone secretion and physiological state of the cow. Data from this study presented elsewhere (Roche et al., 2008a) also indicate an increase in the temporal pattern of circulating growth hormone in the GHR cows in the current study. Elevated ghrelin concentrations and an already positive change in DMI in early lactation may temper an animal's ability to respond to exogenous administration of ghrelin. Further research is required into the effect of ghrelin administration at different stages of lactation.

Obestatin. In the current study obestatin did not affect DMI. In comparison with the quite extensive body of information on ghrelin, there are limited and inconsistent data regarding the anorexigenic effect of obestatin. The initial report (Zhang et al., 2005) presented an intake and gastric-emptying suppression effect of obestatin, claiming action through binding to the orphan G protein-coupled receptor, GPR39. Subsequent research disputed both the anorexigenic effect of obestatin and its binding to GPR39 (Garg, 2007; Nogueiras et al., 2007). In contrast, however, Zhang et al. (2007), Green et al. (2007), and Lagaud et al. (2007) reported that obestatin reduced food intake when rodents had access to food at precisely $15 \mathrm{~min}$ postinfusion. A recent study (Zizzari et al., 2007) may offer some explanation for the inconsistent effects. They reported an attenuation of the orexigenic effect of ghrelin when mice were treated simultaneously with obestatin, but no anorexigenic effect of obestatin per se. These data may reflect a role for obestatin in the control of the orexigenic effect of ghrelin, rather than an anorexigenic effect. This could also be the reason for the lack of effect in the current study. It is possible that a pulse dose of obestatin, at a time approximate to the release of ghrelin, is required to reduce the hunger signal and DMI. This is also consistent with the need for food precisely $15 \mathrm{~min}$ postobestatin infusion (Lagaud et al., 2007; Zhang et al., 2007), a period during which endogenous ghrelin would be expected to rise (Sugino et al., 2002).

A further reason for the lack of effect of obestatin on DMI in the current study may be that the dose used was not sufficient to elicit an anorexigenic response. The $0.007 \mu \mathrm{mol} / \mathrm{kg}$ of $\mathrm{BW}^{0.75}$ per $\mathrm{d}$ infused was much less than that used in the aforementioned rodent experiments. However, Lagaud et al. (2007) tested a range of obestatin infusion rates and reported an anorexigenic 
effect to acute administrations of obestatin in the 10 to $100 \mathrm{nmol} / \mathrm{kg}$ range in mice, suggesting that obestatin is effective at very low infusion rates.

\section{Body Condition Score}

Rodent studies highlighting an increase in the expression of growth hormone secretagogue receptor in adipose tissue with increased weight gain (Tschop et al., 2004) and increased growth rate following daily injections of ghrelin (Nakahara et al., 2003; Tschop et al., 2004) have led to the general acceptance of ghrelin as a stimulator of adipogenesis (Tschop et al., 2004). This is not consistent with ghrelin's role as a growth hormone secretagogue, nor is it consistent with the greater BCS loss and plasma NEFA concentration, and lesser plasma IGF-1, glucose, and leptin concentrations in ghrelin-infused cows in the study reported here. Despite the aforementioned positive effect of ghrelin infusion on adipogenesis in the rodent models, Zhang et al. (2004) reported an inhibitory role of ghrelin on adipogenesis, with cells overexpressing ghrelin receptors demonstrating significantly attenuated differentiation of preadipocytes into adipocytes and a significant decrease in the activity of peroxisome proliferator-activator receptorgamma. It is possible that the effect of ghrelin on the adipocytes is dependent on the physiological state of that tissue at the time of exposure and that animals in a state of lipolysis may react differently to ghrelin than those in a state of lipogenesis. Further research is required on the effect of ghrelin on the metabolism of adipose tissue in dairy cows and how this is affected by stage of lactation.

\section{Milk Production and Blood Metabolites}

Treatment with ghrelin or obestatin did not affect cumulative or daily milk yield or composition, in contrast to the increased milk yield reported by Nakahara et al. (2003) in lactating rats injected with a similar amount of ghrelin (per $\mathrm{kg}$ of $\mathrm{BW}^{0.75}$ ). Although there was no significant effect of treatment on milk production in the current study, there was a numerical separation of the milk profiles after approximately wk 3 of treatment, with GHR cows producing numerically more milk than control or OBE cows (Figure 1). Even though this effect was not statistically significant, it is conspicuous in that the milk profile separation occurs at approximately the same time as the treatment difference in the profile of BCS change occurred (Figure 2a) and the timing of the effect of ghrelin infusion on plasma IGF1 and leptin concentrations. From wk 3 postinfusion, GHR cows lost BCS, whereas the mean trajectory of BCS change in the other 2 groups was flat or slightly increasing. This is reflected in the greater BCS change in GHR cows compared with untreated controls and is consistent with the greater circulating NEFA and lesser IGF-1 and glucose concentration in blood, indicating a greater negative energy balance than the other treatment groups. It is also consistent with the trend toward lesser plasma leptin concentrations, reflecting a lesser fat mass in the GHR cows. Also consistent with the timing of the ghrelin infusion effect on the lactation profile and the profile of BCS change is the interaction between the effect of ghrelin on plasma IGF-1 and leptin concentration and time, with the treatment effect only becoming evident from wk 3 postpump infusion. These indicators of greater negative energy balance in GHR cows after wk 3 suggest that the difference in milk production, although not statistically significant, may in fact be real.

A further point worth considering is that it is at this point of lactation (approximately $7 \mathrm{wk}$ postcalving) that we would expect bST to have its effect on milk yield (Richards et al., 1985). Ghrelin was first discovered as an endogenous ligand for the growth hormone secretagogue receptor, with specific growth hormone releasing activity via a direct pituitary action (Kojima et al., 1999). This growth hormone releasing action would be expected to increase milk production in much the same way as an equivalent dose of bST, and as Richards et al. (1985) reported for bST, this would not be expected to increase milk production until animals were in positive energy balance (approximately 50 DIM). In addition, growth hormone would also explain the greater loss of BCS in GHR cows (Bauman, 1992) with the initial increase in milk yield from bST fuelled by tissue mobilization and subsequently by increased DMI. Although presented data do not indicate an effect of treatment on plasma growth hormone at a single point, data from this study (Roche et al., 2008a) indicate an increase in circulating growth hormone concentrations during periods of feeding inactivity in GHR cows. Further work is required to determine if the numerical increase in milk yield with ghrelin infusion is real, and if so if this increase is a result of ghrelin's effect on growth hormone secretion or some other factor.

\section{CONCLUSIONS}

Exogenous infusion of ghrelin or obestatin did not significantly affect DMI or milk production in early lactation dairy cows, although there was a numerical increase in milk yield in ghrelin-infused cows around $3 \mathrm{wk}$ postinfusion. The point of separation in the milk profiles is consistent with greater BCS loss in GHR cows, and differences in blood metabolites and hormones indicative of greater negative energy balance. 
Further research is required to determine the effect of these hormones in mid- and late-lactation, when peak DMI has been reached and animals are in positive energy balance.

\section{ACKNOWLEDGMENTS}

The authors acknowledge the technical assistance of J. Lee, P. Aspin, K. Watkins, and P. Gore, the statistical expertise of B. Dow, all the help afforded them by DairyNZ laboratory and Lye dairy farm staff, and the laboratory expertise of Alpha Scientific, Hamilton, New Zealand and the University of Western Australia, Perth, Australia. This work was funded by New Zealand Dairy Farmers through DairyNZ.

\section{REFERENCES}

Aydin, S., H. Geckilb, F. Zenginc, H. I. Ozercand, F. Karatasg, S. Aydinf, D. Turgut-Balikc, Y. Ozkane, F. Daglid, and V. Celikc. 2006. Ghrelin in plants: What is the function of an appetite hormone in plants? Peptides 27:1597-1602.

Bauman, D. E. 1992. Bovine somatotropin: Review of an emerging technology. J. Dairy Sci. 75:3432-3451.

Bednarek, M. A., S. D. Feighner, S. S. Pong, K. Kulju McKee, D. L. Hreniuk, M. V. Silva, V. A. Warren, A. D. Howard, L. H. Y. Van der Ploeg, and J. V. Heck. 2000. Structure-function studies on the new growth hormone-releasing peptide, ghrelin: Minimal sequence of ghrelin necessary for activation of growth hormone Secretagogue receptor 1a. J. Med. Chem. 43:4370-4376.

Blache, D., R. Tellam, L. M. Chagas, M. A. Blackberry, P. V. Vercoe, and G. B. Martin. 2000. Level of nutrition affects leptin concentrations in plasma and cerebrospinal fluid in sheep. J. Endocrinol. 165:625-637.

Downing, J. A., J. Joss, P. Connell, and R. J. Scaramuzzi. 1995. Ovulation rate and the concentrations of gonadotrophic and metabolic hormones in ewes fed lupin grain. J. Reprod. Fertil. 103:137-145.

Forbes, J. M., and F. D. Provenza. 2000. Integration of learning and metabolic signals into a theory of dietary choice and food intake. Pages 3-20 in Ruminant Physiology. Digestion, Metabolism, Growth and Reproduction. P. B. Cronje, ed. CABI, New York, NY.

Garg, J. 2007. The ongoing saga of obestatin: Is it a hormone? Clin. Endocrinol. Metab. 92:3396-3398.

Gluckman, P. D., J. J. Johnson-Barrett, J. H. Butler, B. W. Edgar, and T. R. Gunn. 1983. Studies of insulin-like growth factor-I and -II by specific radioligand assays in umbilical cord blood. Clin. Endocrinol. (Oxf.) 19:405-413.

Green, B. D., N. Irwin, and P. R. Flatt. 2007. Direct and indirect effects of obestatin peptides on food intake and the regulation of glucose homeostasis and insulin secretion in mice. Peptides 5:981-987.

Hales, C. N., and P. J. Randle. 1963. Immunoassay of insulin with insulin-antibody precipitate. Biochem. J. 88:137-146.

Harrison, J. L., D. W. Miller, P. A. Findlay, and C. L. Adam. 2008. Photoperiod influences the central effects of ghrelin on food intake, GH and LH secretion in sheep. Neuroendocrinology 87:182-192.

Hayashida, T., K. Murakami, K. Mogi, M. Nishihara, M. Nakazato, M. S. Mondal, Y. Horii, M. Kojima, K. Kangawa, and N. Murakami. 2001. Ghrelin in domestic animals: Distribution in stomach and its possible role. Domest. Anim. Endocrinol. 21:17-24.

Ingvartsen, K. L., and J. B. Andersen. 2000. Integration of metabolism and intake regulation: A review focusing on periparturient animals. J. Dairy Sci. 83:1573-1597.
Iqbal, J., T. Kurose, B. Canny, and I. J. Clarke. 2006. Effects of central infusion of ghrelin on food intake and plasma levels of growth hormone, luteinizing hormone, prolactin, and cortisol in sheep. Endocrinology 147:510-519.

Itoh, F., T. Komatsu, S. Kushibiki, and K. Hodate. 2006. Effects of ghrelin injection on plasma concentrations of glucose, pancreatic hormones and cortisol in Holstein dairy cattle. Comp. Biochem. Physiol. A 143:97-102.

Itoh, F., T. Komatsu, M. Yonai, T. Sugino, M. Kojima, K. Kangawa, Y. Hasegawa, Y. Terashima, and K. Hodate. 2005. GH secretory responses to ghrelin and GHRH in growing and lactating dairy cattle. Domest. Anim. Endocrinol. 28:34-45.

Kennedy, G. C. 1953. The role of depot fat in the hypothalamic control of food intake in the rat. Proc. R. Soc. Lond. 140:578-592.

Kennedy, J., P. Dillon, L. Delaby, P. Faverdin, G. Stakelum, and M. Rath. 2003. Effect of genetic merit and concentrate supplementation on grass intake and milk production with Holstein Friesian dairy cows. J. Dairy Sci. 86:610-621.

Kojima, M., H. Hosoda, Y. Date, M. Nakazato, H. Matsuo, and K. Kangawa. 1999. Ghrelin is a growth-hormone-releasing acylated peptide from stomach. Nature 402:656-660.

Lagaud, G. J., A. Young, A. Acena, M. F. Morton, T. D. Barrett, and N. P. Shankley. 2007. Obestatin reduces food intake and suppresses body weight gain in rodents. Biochem. Biophys. Res. Commun. $357: 264-269$.

MacGibbon, A. K. H. 1988. Modified method of fat extraction for solid fat content determination. N. Z. J. Dairy Sci. Technol. 23:399403.

Murphy, K. G., and S. R. Bloom. 2006. Gut hormones and the regulation of energy homeostasis. Nature 444:854-859.

Nakahara, K., T. Hayashida, M. Nakazato, M. Kojima, H. Hosoda, K. Kangawa, and N. Murakami. 2003. Effect of chronic treatments with ghrelin on milk secretion in lactating rats. Biochem. Biophys. Res. Commun. 303:751-755.

Neary, N. M., C. J. Small, A. M. Wren, J. L. Lee, M. R. Druce, C. Palmieri, G. S. Frost, M. A. Ghatei, R. C. Coombes, and S. R. Bloom. 2004. Ghrelin increases energy intake in cancer patients with impaired appetite: Acute, randomized, placebo-controlled trial. J. Clin. Endocrinol. Metab. 89:2832-2836.

Nogueiras, R., P. Pfluger, S. Tovar, M. Arnold, S. Mitchell, A. Morris, D. Perez-Tilve, M. J. Vázquez, P. Wiedmer, T. R. Castañeda, R. DiMarchi, M. Tschöp, A. Schurmann, H.-G. Joost, L. M. Williams, W. Langhans, and C. Diéguez. 2007. Effects of obestatin on energy balance and growth hormone secretion in rodents. Endocrinology 148:21-26.

Richards, A. L., S. N. McCutcheon, and D. E. Bauman. 1985. Responses of dairy cows to exogenous bovine growth hormone administered during early lactation. J. Dairy Sci. 68:2385-2389.

Roche, J. R., P. G. Dillon, C. R. Stockdale, L. H. Baumgard, and M. J. VanBaale. 2004. Relationships among international body condition scoring systems. J. Dairy Sci. 87:3076-3079.

Roche, J. R., A. J. Sheahan, D. P. Berry, L. Chagas, D. Blache, and J. Kay. 2008a. Effect of ghrelin or obestatin continuously infused to dairy cows on grazing and ruminating behavior and plasma hormone and metabolite concentrations. J. Dairy Sci. 91(Suppl. 1):73.

Roche, J. R., A. J. Sheahan, L. M. Chagas, and D. P. Berry. 2006. Genetic selection for milk production increases plasma ghrelin concentration in pasture-based dairy cows. J. Dairy Sci. 89:34713475 .

Roche, J. R., A. J. Sheahan, L. M. Chagas, and D. P. Berry. 2007. Concentrate supplementation reduces postprandial plasma ghrelin in grazing dairy cows: A possible neuro-endocrine basis for reduced pasture intake in supplemented cows. J. Dairy Sci. 90:13541363.

Roche, J. R., A. J. Sheahan, L. M. Chagas, and R. C. Boston. 2008b. Change in plasma ghrelin in dairy cows following an intra-venous glucose challenge. J. Dairy Sci. 91:1005-1010.

SAS. 2007. User's Guide Version 9.2: Statistics. SAS Institute, Cary, $\mathrm{NC}$ 
Shiiya, T., M. Nakazato, M. Mizuta, Y. Date, M. S. Mondal, M Tanaka, S.-I. Nozoe, H. Hosoda, K. Kangawa, and S. Matsukura. 2002. Plasma ghrelin levels in lean and obese humans and the effect of glucose on ghrelin secretion. J. Clin. Endocrinol. Metab. $87: 240-244$.

Stanley, S., K. Wynne, B. McGowan, and S. Bloom. 2005. Hormonal regulation of food intake. Physiol. Rev. 85:1131-1158.

Sugino, T., Y. Hasegawa, Y. Kikkawa, J. Yamaura, M. Yamagishi, Y. Kurose, M. Kojima, K. Kangawa, and Y. Terashima. 2002. A transient ghrelin surge occurs just before feeding in a scheduled meal-fed sheep. Biochem. Biophys. Res. Commun. 295:255-260.

Tschop, M. H., T. Castaneda, and U. Pagotto. 2004. Ghrelin food intake and energy balance. Pages 91-112 in Ghrelin. E. Ghigo, A. Benso, and F. Broglio, ed. Kluwer Academic Publishers, Boston, MA.

Wertz-Lutz, A. E., T. J. Knight, R. H. Pritchard, J. A. Daniel, J. A. Clapper, A. J. Smart, A. Trenkle, and D. C. Beitz. 2006 Circulating ghrelin concentrations fluctuate relative to nutritional status and influence feeding behavior in cattle. J. Anim. Sci. 84:3285-3300.

Zhang, J. V., C. Klein, P. G. Ren, S. Kass, L. V. Donck, D. Moechars, and A. J. W. Hsueh. 2007. Response to comment on "Obestatin, a peptide encoded by the ghrelin gene, opposes ghrelin's effects on food intake". Science 315:766

Zhang, J. V., P. G. Ren, O. Avsian-Kretchmer, C. W. Luo, R. Rauch, C. Klein, and A. J. Hsueh. 2005. Obestatin, a peptide encoded by the ghrelin gene, opposes ghrelin's effects on food intake. Science 310:996-999.

Zhang, W., L. Zhao, T. R. Lin, B. Chai, Y. Fan, I. Gantz, and M. W. Mulholland. 2004. Inhibition of adipogenesis by ghrelin. Mol. Biol Cell 15:2484-2491.

Zizzari, P., R. Longchamps, J. Epelbaum, and M. T. Bluet-Pajot. 2007. Obestatin partially affects ghrelin stimulation of food intake and growth hormone secretion in rodents. Endocrinology 148:1648-1653. 